\title{
Lignocaine and Esmolol on Stress Response to Laryngoscopy and Intubation
}

\author{
Pradeep Kumar Rajbhandari ${ }^{1}$ \\ 'Department of Anesthesia, Kathmandu Model Hospital, Kathmandu, Nepal.
}

\begin{abstract}
Introduction: Laryngoscopy and tracheal intubation causes significant sympathetic response resulting in hypertension and tachycardia. In individuals with systemic hypertension, coronary artery disease, cerebrovascular disease and intracranial aneurysm, the effect of this transient sympathetic response can evoke life threatening conditions like pulmonary oedema, cardiac failure and cerebrovascular haemorrhage.
\end{abstract}

Methods: Patients were randomly divided into two groups, 30 in each group. Group I received 50 $\mathrm{mg}$ of esmolol and group II received lignocaine $2 \mathrm{mg} / \mathrm{kg}$. Haemodynamic parameters like pulse, systolic blood pressure, diastolic blood pressure and mean arterial pressure were measured before induction of anaesthesia, immediately after intubation then at intervals of one minute, three minutes, five minutes, seven minutes and 10 minutes.

Results: There was no significant difference in demographic or base line vital signs between two groups (Table 1). The mean systolic blood pressure (SBP) increased on laryngoscopy and tracheal intubation by $15 \mathrm{mmHg}$ in the group I whereas in group II it was $17.4 \mathrm{mmHg}$. There was a significant rise in diastolic blood pressure (DBP) in both the groups, but the rise was lesser in group II than in group I.

Conclusion: Both esmolol and lignocaine were not effective in attenuating hemodynamic stress response to laryngoscopy and tracheal intubation; however esmolol was superior to lignocaine in blunting the stress response.

Keywords: esmolol; intubation; laryngoscopy; lignocaine; stress response.

\section{INTRODUCTION}

Laryngoscopy and tracheal intubation are noxious stimuli that produce marked sympathetic response manifesting as hypertension and tachycardia. ${ }^{1}$ In susceptible individuals, especially those with systemic hypertension, coronary artery disease, cerebrovascular disease and intracranial aneurysm, the effect of this transient sympathetic response can evoke life threatening conditions, ${ }^{2}$ and have been recognized as a potential source of a number of complications, including pulmonary oedema, cardiac failure and cerebrovascular haemorrhage.

Correspondence: Dr. Pradeep Kumar Rajbhandari, Kathmandu Model Hospital, Exhibition Road, Kathmandu, Nepal. Email: prakura@ gmail.com, Phone: +977-1-4240806. 
Direct laryngoscopy and endotracheal intubation frequently induces a cardiovascular stress response characterized by hypertension and tachycardia due to reflex sympathetic simulation. The response is transient; occurring 30 seconds after intubation and lasting for less than 10 minutes. $^{3}$ It may be well tolerated in healthy people, but may be hazardous in patients with hypertension, coronary artery disease, cerebrovascular disease, myocardial infarction and thyrotoxicosis. ${ }^{4}$

\begin{tabular}{|llll|}
\hline \multicolumn{4}{|l|}{ Table1. Demographic Data of the Patients. } \\
\hline $\begin{array}{l}\text { Charac- } \\
\text { teristics }\end{array}$ & Esmolol & Lignocaine & $\begin{array}{l}\text { Signifi- } \\
\text { Group I }\end{array}$ \\
$\begin{array}{l}\text { Age [years] } \\
\text { Group II }\end{array}$ & $38.3 \pm 9.8$ & $36.5 \pm 9.8$ & $\mathrm{p}=0.47$ \\
$\begin{array}{l}\text { Seight [kg] } \\
\text { SurgeryTime } \\
\text { [minute] }\end{array}$ & $71.7 \pm 40.1$ & $68.3 \pm 39.7$ & $\mathrm{p}=0.74$ \\
$\begin{array}{l}\text { Basal heart } \\
\text { rate [Bpm] }\end{array}$ & $82.2 \pm 15.4$ & $85.1 \pm 14.4$ & - \\
$\begin{array}{l}\text { Basal SBP } \\
\text { [mm Hg] }\end{array}$ & $128.5 \pm 18.3$ & $128.4 \pm 14.1$ & - \\
$\begin{array}{l}\text { Basal DBP } \\
\text { [mm Hg] }\end{array}$ & $78.4 \pm 10.1$ & $78.5 \pm 10.7$ & - \\
$\begin{array}{l}\text { MAP [ } \\
\text { mmHg] }\end{array}$ & $100.4 \pm 12.2$ & $99.2 \pm 12$ & - \\
\hline
\end{tabular}

Recently, it has been demonstrated that there is an increase in plasma concentration of adrenaline and noradrenaline to this stimuli. ${ }^{5,6}$ The cardiovascular response to laryngoscopy and tracheal intubation include hypertension, tachycardia and compromise in myocardial oxygen demand and supply ratio leading to myocardial ischaemia and subsequently various types of dysarrythmias. In 1940, Reid and Brace were the first to report the circulatory response to laryngeal and tracheal stimulation in anaesthetized man. These were tachycardia and rise in arterial blood pressure. ${ }^{7}$

In 1964, Takeshima, Noda and Higaki found a mean rise in arterial blood pressure of $20 \mathrm{mmHg}$ at the time of laryngoscopy and tracheal intubation. From this they concluded that laryngoscopy was a more potent stimulus for hypertension than intubation. ${ }^{19}$

Various methods have been suggested to attenuate these responses including the use of a variety of inhalation anaesthetic agents, calcium channel blockers, narcotics, magnesium, alpha-2 agonist, betablockers, local anaesthetic agents and combination of these drugs. A combination of esmolol and alfentanil has been shown to reliably suppress the response to laryngoscopy and intubation. Local anaesthetics such as lignocaine and chloroprocaine were tried in both forms topical as well as intravenous, where intravenous lidocaine and chloroprocaine showed promising results.

\section{METHODS}

A prospective double blind comparative study was conducted in Bir Hospital among patients who underwent surgery under general anaesthesia. Sixty patients with American society of anaesthesiologist (ASA) - I and II were included in the study after obtaining institutional approval and written informed consent. Following patients were excluded:

1. Patients who did not meet the criteria for ASA I and II.

2. Patients with difficult laryngoscopy and intubation.

3. Patients with history of hypertension and cardiovascular disease.

4. Patients with history of allergy to lignocaine and esmolol.

Patients were randomly divided into two groups. Group I-esmolol $[n=30]$ and group II-lignocaine $[n=30]$. Group I received esmolol $50 \mathrm{mg}$ bolus and group II received lignocaine $2 \mathrm{mg} / \mathrm{kg}$ body weight. All patients were premedicated with diazepam $5 \mathrm{mg}$ ( $<50 \mathrm{~kg}$ body weight) and $10 \mathrm{mg}$ ( $>50 \mathrm{~kg}$ body weight) orally at night.

Table 2. Comparison of haemodynamic variables between esmolol and lignocaine [HR, DBP and MAP] just after laryngoscopy and tracheal intubation.

\begin{tabular}{llll}
\hline $\begin{array}{l}\text { After } \\
\text { laryngoscopy } \\
\text { and tracheal } \\
\text { intubation }\end{array}$ & Esmolol & Lignocaine & $p$-value \\
$\begin{array}{l}\text { Heart rate [HR] } \\
\text { bpm }\end{array}$ & $\begin{array}{l}100.7 \pm \\
13.3\end{array}$ & $114.8 \pm 17.5$ & 0.001 \\
$\begin{array}{l}\text { Systolic blood } \\
\text { pressure [SBP] }\end{array}$ & $143.5 \pm$ & $145.8 \pm 20.5$ & 0.690 \\
$\begin{array}{l}\text { [mmHg] } \\
\text { Diastolic blood } \\
\text { pressure [DBP] }\end{array}$ & $99.7 \pm$ & $97.9 \pm 13.1$ & 0.640 \\
$\begin{array}{l}\text { [ mmHg] } \\
\text { Mean arterial } \\
\text { pressure [MAP] }\end{array}$ & $118.1 \pm$ & $116.1 \pm 14.6$ & 0.630 \\
{$[$ mmHg] } & 18.2 & & \\
\hline
\end{tabular}

After receiving the patient in operation theatre, an intravenous line was secured and continuous monitoring (ECG, pulse oxymetry and NIBP) was started after prehydrated with $500 \mathrm{ml}$ of ringer lactate solution. The base line values [heart rate, SBP, DBP and Mean Arterial Pressure (MAP)] were recorded. Patients were randomly allocated to receive either intravenous (IV) esmolol 50 $\mathrm{mg}$ bolus or IV lignocaine $2 \mathrm{mg} / \mathrm{kg}$ body weight and drug was given two minutes before induction. 
Anaesthesia was induced with IV pethidine $0.5 \mathrm{mg} / \mathrm{kg}$, IV sodium thiopentone $5 \mathrm{mg} / \mathrm{kg}$ and IV succinylcholine $2 \mathrm{mg} / \mathrm{kg}$ was given to facilitate intubation. One minute after IV administration of succinylcholine and three minutes after the trial drug, laryngoscopy was performed and trachea intubated with an endotracheal tube and ventilated with oxygen and halothane. Relaxation was provided by IV vecuronium in the dose of $0.08 \mathrm{mg} / \mathrm{kg}$ and supplemented with $1 / 4^{\text {th }}$ of initial dose whenever necessary.

\begin{tabular}{|c|c|c|c|}
\hline $\begin{array}{l}1 \text { minute } \\
\text { after } \\
\text { intubation }\end{array}$ & Esmolol & Lignocaine & $\mathrm{p}$-value \\
\hline $\begin{array}{l}\text { Heart rate } \\
{[\mathrm{HR}][\mathrm{bpm}]}\end{array}$ & $94.0 \pm 13.3$ & $104.6 \pm 15.7$ & 0.006 \\
\hline $\begin{array}{l}\text { Systolic } \\
\text { blood } \\
\text { pressure } \\
\text { [SBP] } \\
{[\mathrm{mmHg}]}\end{array}$ & $129.0 \pm 20.3$ & $126.0 \pm 13.8$ & 0.610 \\
\hline $\begin{array}{l}\text { Diastolic } \\
\text { blood } \\
\text { pressure } \\
\text { [DBP] } \\
{[\mathrm{mmHg}]}\end{array}$ & $88.1 \pm 14.2$ & $83.8 \pm 31.1$ & 0.220 \\
\hline $\begin{array}{l}\text { Mean arterial } \\
\text { pressure } \\
{[\mathrm{MAP}]} \\
{[\mathrm{mmHg}]}\end{array}$ & $103.5 \pm 16.2$ & $101.0 \pm 13.4$ & 0.520 \\
\hline
\end{tabular}

Haemodynamic variables were recorded immediately after intubation and after one, three, five, and seven and 10 minutes of intubation. During these 10 minutes, all surgical stimulations were avoided. Heart rate and blood pressure were recorded every 10 minutes till the end of surgery. At the end of surgery, the effects of muscle relaxant were reversed with $0.05 \mathrm{mg} / \mathrm{kg}$ of IV neostigmine and $0.02 \mathrm{mg} / \mathrm{kg}$ of IV atropine.

\section{RESULTS}

Out of 60 patients involved, age in group I varied from 21 to 55 years (mean $38.3 \pm 9.8$ years). In group II, the age ranged from 20 to 55 years $(36.5 \pm 9.8$ years). There were nine males and 21 females in group I and 11 males and 19 females in group II.

\begin{tabular}{|c|c|c|c|}
\hline $\begin{array}{l}3 \text { minutes } \\
\text { after } \\
\text { intubation }\end{array}$ & Esmolol & Lignocaine & $\mathrm{p}$-value \\
\hline $\begin{array}{l}\text { Heart rate } \\
{[\mathrm{HR}][\mathrm{bpm}]}\end{array}$ & $81.6 \pm 12.0$ & $88.2 \pm 15.6$ & 0.07 \\
\hline $\begin{array}{l}\text { Systolic blood } \\
\text { pressure } \\
\text { [SBP] [mmHg] }\end{array}$ & $106.5 \pm 19.5$ & $\begin{array}{l}111.3 \pm \\
13.5\end{array}$ & 0.27 \\
\hline $\begin{array}{l}\text { Diastolic } \\
\text { blood } \\
\text { pressure } \\
\text { [DBP][mmHg] }\end{array}$ & $70.6 \pm 13.9$ & $\begin{array}{l}71.5 \pm \\
11.5\end{array}$ & 0.78 \\
\hline $\begin{array}{l}\text { Mean arterial } \\
\text { pressure } \\
\text { [MAP] [ } \\
\text { mmHg] }\end{array}$ & $84.9 \pm 14.7$ & $85.8 \pm 9.1$ & 0.76 \\
\hline
\end{tabular}

Table 5. Haemodynamic variables five minutes after intubation.

\begin{tabular}{llll}
\hline $\begin{array}{l}5 \text { minutes } \\
\text { after } \\
\text { intubation }\end{array}$ & Esmolol & Lignocaine & $\begin{array}{l}\mathrm{p} \text { - } \\
\text { value }\end{array}$ \\
$\begin{array}{l}\text { Heart rate } \\
\text { [HR] [bpm] } \\
\text { Systolic blood } \\
\text { pressure [SBP] }\end{array}$ & $100.1 \pm 18.3$ & $100.6 \pm 13.5$ & 0.89 \\
[mmHg] & $80.0 \pm 13.7$ & 0.19 \\
$\begin{array}{l}\text { Diastolic } \\
\text { blood pressure }\end{array}$ & $65.1 \pm 12.9$ & $63.8 \pm 11.6$ & 0.68 \\
[DBP] [mmHg] & & & \\
$\begin{array}{l}\text { Mean arterial } \\
\text { pressure }\end{array}$ & $77.8 \pm 15.4$ & $79.6 \pm 10.3$ & 0.61 \\
[MAP] mmHg] & & & \\
\hline
\end{tabular}

Table 6. Haemodynamic variables seven minutes after tracheal intubation.

\begin{tabular}{|l|l|l|l|}
\hline $\begin{array}{l}7 \text { minutes after } \\
\text { intubation }\end{array}$ & Esmolol & Lignocaine & $\begin{array}{l}\mathrm{p} \text { - } \\
\text { value }\end{array}$ \\
$\begin{array}{l}\text { Heart rate [HR] } \\
\text { [bpm] }\end{array}$ & $70.0 \pm 15.9$ & $76.0 \pm 13.7$ & 0.07 \\
$\begin{array}{l}\text { Systolic blood } \\
\text { pressure [SBP] } \\
\text { [mmHg] }\end{array}$ & $102.5 \pm 15.9$ & $96.1 \pm 12.3$ & 0.08 \\
$\begin{array}{l}\text { Diastolic blood } \\
\text { pressure [DBP][ } \\
\text { mmHg] }\end{array}$ & $67.3 \pm 12.4$ & $62.6 \pm 11.8$ & 0.14 \\
$\begin{array}{l}\text { Mean arterial } \\
\text { pressure [MAP] } \\
\text { mmHg] }\end{array}$ & $80.6 \pm 14.8$ & $74.0 \pm 10.5$ & 0.05 \\
\hline
\end{tabular}




\begin{tabular}{|lccl|}
\hline $\begin{array}{l}\text { Table } 7 . \text { Haemodynamic variables } \\
\text { tracheal intubation. }\end{array}$ & minutes & after \\
\hline $\begin{array}{l}10 \text { minutes } \\
\text { after intubation }\end{array}$ & Esmolol & Lignocaine & $\begin{array}{l}\mathrm{p} \text { - } \\
\text { value }\end{array}$ \\
$\begin{array}{l}\text { Heart rate [HR] } \\
\text { [bpm] }\end{array}$ & $72.0 \pm 15.0$ & $72.9 \pm 15.2$ & 0.02 \\
$\begin{array}{l}\text { Systolic blood } \\
\text { pressure [SBP] } \\
\text { [mmHg] }\end{array}$ & $102.5 \pm 16.3$ & $98.0 \pm 14.3$ & 0.26 \\
$\begin{array}{l}\text { Diastolic blood } \\
\text { pressure [DBP] } \\
\text { mmHg] }\end{array}$ & $68.0 \pm 14.5$ & $62.6 \pm 12.4$ & 0.13 \\
$\begin{array}{l}\text { Mean arterial } \\
\text { pressure [MAP] } \\
\text { [mmH] }\end{array}$ & $80.1 \pm 15.0$ & $76.5 \pm 14.2$ & 0.34 \\
\hline
\end{tabular}

\section{DISCUSSION}

The precise mechanism which leads to the haemodynamic response to laryngoscopy and tracheal intubation probably involves intense sympathetic discharges caused by stimulation of epipharynx and laryngopharrynx. ${ }^{3}$ Hassan concluded that during laryngoscopy and endotracheal intubation placing of tube through the cords and inflating the cuff in infraglottic region contributes significantly to sympathoadrenal response caused by supraglottic stimulation. ${ }^{8}$ Shribman et al showed in 24 patients undergoing elective surgery, that laryngoscopy alone increased blood pressure and that laryngoscopy and intubation together increased both $\mathrm{HR}$ and BP. ${ }^{5}$ The study also demonstrated an increase in serum catecholamine levels during laryngoscopy with and without concomitant intubation, which is a possible cause of these haemodynamic changes.

The cardiovascular response to laryngoscopy and tracheal intubation includes hypertension and tachycardia and compromises in myocardial oxygen demand and supply ratio leading to myocardial ischaemia and subsequently various types of dysarrythmias. ${ }^{9}$

This study was undertaken to compare the effectiveness of lignocaine and esmolol in blunting the stress response to laryngoscopy and tracheal intubation and also to find out change in heart rate and blood pressure [SBP, DBP and MAP].

In this study where esmolol was administered, heart rate increased in an average by 18.5 bpm just after laryngoscopy and tracheal intubation $(p<0.001)$ and normalized to its base line value in three minutes $(p=0.83)$. However, esmolol could not attenuate the heart rate in response to laryngoscopy and tracheal intubation. Moreover, increase in heart rate was less in comparison to group. Other studies have shown that esmolol could not attenuate intubation reflex completely which is consistent with the findings from this study. Chunk KS et al, used esmolol $2 \mathrm{mg} / \mathrm{kg}$ two minutes before RSI of anaesthesia and found that heart rate was increased in $34 \%$ patients $(p<0.05) .{ }^{10}$ In the same way, Helfman SM et al used esmolol 150 $\mathrm{mg}$ two minutes before intubation and noted that heart rate increased in $18 \% \pm 5 \%[p<0.05] .11$ Kindler $\mathrm{CH}$, Schumacher PG et al used esmolol $1 \mathrm{mg} / \mathrm{kg}$ and 2 $\mathrm{mg} / \mathrm{kg}$ and found that in both doses of esmolol the proportion of patients with a maximum HR exceeding $90 \mathrm{bpm}$ is same ( in 2 of 15 ) [p<0.05]. ${ }^{12}$

Rathore A et al, found that $50 \mathrm{mg}, 100 \mathrm{mg}$ and 150 $\mathrm{mg}$ of esmolol hydrochloride could not blunt the HR in response to laryngoscopy and intubation. ${ }^{13}$

In the same way, Feng CK et al, also used esmolol 2 $\mathrm{mg} / \mathrm{kg}$ three minutes before intubation and they found incidence of tachycardia [heart rate $>100 \mathrm{bpm}$ ] in three out of 20 [15\%] patients significantly lower than 17 of $20(85 \%)$ in controlled group. ${ }^{14}$

Miller DR et al, demonstrated that a $100 \mathrm{mg}$ bolus of esmolol is safe and effective for controlling the haemodynamic response to tracheal intubation. ${ }^{15}$ In this study, potent opioids (fentanyl or sufentanyl ) were used but in our study pethidine was used.

In lignocaine group of our study, heart rate was increased by an average $29.7 \mathrm{bpm}$ following laryngoscopy and tracheal intubation ( $p=<0.001)$ and it was decreased to its baseline value in five minutes of intubation $(p=0.04)$. It showed that lignocaine was not effective in attenuating heart rate in response to tracheal intubation. Other studies also reported that lignocaine did not attenuate heart rate in response to tracheal intubation.

Singh $\mathrm{H}$ et al, ${ }^{16}$ Kindler $\mathrm{CH}$ et al, ${ }^{12} \mathrm{Kim} \mathrm{WY}$ et al, ${ }^{17}$ and Wilson IG et al, ${ }^{18}$ reported that lidocaine $1.5 \mathrm{mg} / \mathrm{kg}$, was ineffective in controlling heart rate in response to tracheal intubation found that $1.5 \mathrm{mg} / \mathrm{kg}$ lidocaine was not able to control heart rate in response to laryngoscopy and intubation.

\section{CONCLUSIONS}

Our study showed that $50 \mathrm{mg}$ of esmolol and $2 \mathrm{mg} /$ $\mathrm{kg}$ of lignocaine could not attenuate the hemodynamic stress response produced by laryngoscopy and tracheal intubation. The mean heart rate was increased in esmolol and lignocaine groups by an average of 18.5 bpm and $29.7 \mathrm{bpm}$ respectively $(\mathrm{p}<0.001)$ just after intubation. These values were normalized to its baseline values only after three minutes of intubation in esmolol 
and five minutes in lignocaine $(p=0.83,0.33)$. After that, mean heart rate was decreased significantly in both groups.

Likewise, SBP increased significantly in both groups, in esmolol group by an average of $18 \mathrm{mmHg}$ and in lignocaine by $17.4 \mathrm{mmHg}$ with $p<0.001$ and the SBP values came down its basal values only after one minute with $p=0.88$ and $p=0.55$ respectively. After that, SBP was decreased significantly in both groups.

In the same way, DBP was increased by an average of $21.3 \mathrm{mmHg}$ in esmolol group and by $19.4 \mathrm{mmHg}$ in lignocaine group $(p<0.001)$ and came down to its baseline value only after three minutes of intubation $(p=0.002,0.001)$. After that, DBP was decreased below baseline values till 10 minutes.

This study showed that both drugs with specified quantities are not effective in blunting haemodynamic stress response produced by laryngoscopy and tracheal intubation. However, esmolol is better than lignocaine to attenuate the stress response.

\section{REFERENCES}

1. Thompson IR. The haemodynamic response to intubation: a prospective. Can J Anaesth. 1989;36(4):367-9.

2. Prys-Roberts C, Green LT, Meloche R, Foex P. Studies of anaesthesia in relation to hypertension II, haemodynamic consequences of induction and endotracheal intubation. Br J Anaesth. 1971;43:531-47.

3. Stoelting RK. Circulatory changes during direct laryngoscopy and tracheal intubation: influence of duration of laryngoscopy with and without lidocain. Anesthesiology. 1977;17(1):381-4.

4. Fox EJ, Sklar GS, Hill CH, Villanueva R, King BD. Complication related to pressor response to endotracheal intubation. Anesthesiology. 1977;47:524-5.

5. Shribman AJ, Smith G, Achola KJ. Cardiovascular and catecholamine response to laryngoscopy with and without tracheal intubation. Br J Anaesth. 1987;59;295-9.

6. Oczenki W, Krenn H, Dahaba AA, Binder M, El-Schahawi-Kienzi I, Jellinec $\mathrm{H}$ et al. Haemodynamic and catecholamine stress response on insertion of the combitube, laryngeal mask airway or tracheal intubation. Anaesth Analg. 2000;90:231-2.

7. Reid LC, Brace DE. Irritation of the respiratory tract and its reflex upon the heart. Surg Gynecol Obstet. 1940;70:157-62.

8. Hassan HG, EI-Sharkawy TY, Renk H, Mansour G, Fouda A. Haemodynamic and cathecholamine response to laryngoscopy with Vs without endotracheal intubation. Acta Anaesthesiol Scand. 1991;35(5):442-7.

9. Prys-Roberts C, Meloche R, Foex P. Studies of anaesthesia in relation to hypertension I: cardiovascular responses of treated and untreated patients. Br. J. Anaesth. 1971;43:22-37.

10. Chung KS, Sinatra RS, Halevy JD, Paige D, Silver man DG. A comparison of fentanyl, esmolol and their combination for blunting the haemodynamic responses during rapid sequence induction. Can J Anesth. 1992;39(8):774-9.

11. Helfman SM, Gold MI, DeLisser EA, Herrington CA. Which drug prevents tachycardia and hypertension associated with tracheal intubation: lidocaine, fentanyl.or esmolol. Anaesth Analg. 1991;72:482-6.

12. Kindler $\mathrm{CH}$, Schumacher $\mathrm{PG}$, Schneider $\mathrm{MC}$, Urwyler A. Effects of intravenous lidocaine and /or esmolol on hemodynamic responses to laryngoscopy and intubation: a double-blind, controlled clinical trial. J Clin Anesth. 1996;8(6):491-6.

13. Rathore A, Gupta HK, Tanwar GL, Rehman H. Attenuation of the pressure response to laryngoscopy and endotracheal intubation with different doses of esmolol. Indian J Anaesth. 2002;46(6):449-52.

14. Feng CK, Chan KH, Liu KN, Or CH, Lee TY. A comparison of lidocaine, fentanyl and esmolol for attenuating of cardiovascular response to laryngoscopy and tracheal intubation. Acta Anaesthesiol Sin. 1996;34(2);61-7.

15. Miller DR, Martineau RJ, O'Brien H, Hull KA, Oliveras L, Hindmarsh $\mathrm{T}$ et al. Effect of_alfentanil on the haemodynamic and catecholamine response to tracheal intubation. Anaesth Analg. 1993;76(5);1040-6.

16. Singh H, Vichitvejpaisal P, Gaines GY, White PF. Comparative effects of lidocaine, esmolol and nitroglycerine in modifying the haemodynamic response to laryngoscopy and intubation. J Clin Anaesth. 1995;7(1):5-8.

17. Kim WY, Lee YS, Ok SJ, Chang MS, Kim JH, Park YC et al. Lidocaine does not prevent bispectral index increases in response to endotracheal intubation. Anaesth Analg. 2006;102:156-9.

18. Wilson IG, Meiklejohn BH, Smith G. Intravenous lignocaine and sympathoadrenal responses to laryngoscopy and intubation: the effect of varying time of injection. Anaesthesia. 1991;46:177-80.

19. Takeshima K, Noda K, Higaki M. Cardiovascular response to rapid anesthesia induction and endotracheal intubation. Anaesth and Anag1. 964;43(2)201-8. 